\title{
TOWARDS A BIBLICAL THEOLOGY OF RELIGION FOR THIS TIME: CRUX AND POSSIBILITIES
}

Dirk Griffioen

De vrijgemaakt-gereformeerde Kerk

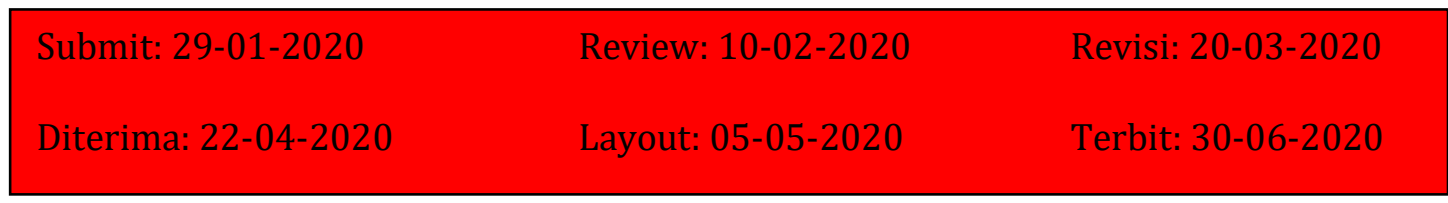

Abstract

In this article I point out that a reformed or practical biblical theology of religion still needs to adapt to our contemporary era. In order to achieve that this research makes use of the efforts made by other people. I am going to focus on the central problem - the questions which I think pertain to religious theology. In the past much attention has been given among us to theological questions but not much has been done to build a system. Hendrik Kraemer was the first missionary to develop a more or less comprehensive theology of religion. One of the results of this research shows that Religion and religions, Christianity and non-Christianity, are phenomena and / or institutions that must be described, compared, and assessed.

Keywords: Missiology, Biblical Theology, Pluralism, Theology of Religion, Exclusivism, Inclusivism

\section{INTRODUCTION}

In this article I should like to make an attempt to draft a reformed or Biblical theology of religion which is practical and appropriate to the time in which we live. In doing so I should like to make use of the attempts made by others $(\S 2)$. I shall concentrate on the central problem - the issues which in my view are concerned with the theology of religion. In the past much attention has been paid in our circles to theological questions but not much has been done to construct a system. Hendrik Kraemer was the first missionary to have developed a more or less comprehensive theologia religionum. Then I shall examine what the possibilities and parameters are for a Reformed or Bibilical theology of religion. I also address the question why this theology needs to be up-to-date, after all we live in the atmosphere of post-modernism. The real question is whether and to what extent the present religious pantheon makes any specific demands on a Biblical or Reformed theology, additional to the 'normal' scientific criteria which must be applied, including the explicit assumptions which are important in the theology of religion.

A crucial section of this contribution is my consideration of religiosity (religious awareness) and religions in $\S 5$. After some general information about what religiosity or religious awareness is, I try to clarify what the nature of religion is. Ultimately this will determine what the view of God (or god), religion and religions is. Opinions globally vary between two extremes: in the view of 
many, religion is a proposition from 'below' of that which is 'above'- or others claim that all religions entirely 'answer' what is God's or what derives from Him. One has to select a position from among all the imaginable hybrid forms: religion has human factors and there is something divine in it. The question is how these two factors relate to each other.

In the following section ( $(6)$ I zoom in deeper into the problem of the relationship between revelation and religion. In the first place this is an attempt to clarify what revelation is and what (how much) of that has come down to us, and what the character and significance of it is, in connection with the shaping of the Christian religion and perhaps also of other religions. The question whether and to what extent the revelation of God is to be found in other religions seems to be crucial. The question as to what is truth is very much bound up with this.

In $\S 7$ which follows I trace lines in Kraemer's development, who more than anyone else has attributed the exclusivity of Christian faith not to the historical development of Christianity but to divine revelation. In this section two questions arise: how the exclusivist standpoint can be maintained, as against the Roman Catholic ecclesiocentrism, and other tendencies towards the absolutism of historical Christianity or of other religions. In conclusion I try to clarify how the interaction between God's revelation and the historical Christianity which developed from it has taken place. Of decisive importance in all this is the question whether and to what extent there is any influence of God's revelation to be perceived in other religions.

Then something must be said in $\S 8$ about the uniqueness and absoluteness of Christian faith in differentiating Christianity, and the relativism which is a necessary consequence of the pluralistic standpoint in theology. In the closing paragraph (9) I sketch a few principals from which lines may be followed to develop a reformed theology of religion. There follow from these a number of issues which in any case must be addressed in this young branch of theology.

\section{METHOD}

The methodology used in this research is based on descriptive methods. Where in part 3 of this article will be decomposed. The question is asked what are the possibilities and limitations, which aids are useful and an outline of which can be used. In $\S 4$ I use Alan Race's general theological model, applying a number of variations. This will prove the extent to which the Race model can be applied, and what the limitations are. What is clear is that the determining elements are religion, Christianity and others. The limitation that comes from this classification model classification is that religion and religion in general are empirical phenomena. In other words, the role of revelation was not well calculated.

\section{DISCUSSION}

One may well wonder how it comes about that a Christian community which has developed a relatively large amount of activities in (world) mission has produced so little comprehensive, more or less established models and systems of thought in order to map out the mysterious relationship between 
Christian faith and the other religions. Certainly every missionary - male or female - has, at least if he is not totally insensitive to the deeper questions of mission, not only met representatives of other religions, but has also become aware of the differences and at the same time the similarities between the religions.

\section{A. Challenges and Motives}

He will also have considered the problems of the comparisons of and the mutual relationship between Christianity and the other religions. In the Reformed world the missiologist Johan Herman Bavinck (1895-1964) has perhaps taken us furthest in revealing the secret of religious diversity and indicating the significance of it. Nearer to us are the missiologists Johannes Verkuyl (1908-2001) and Hendrik Bergema (1902-2007) who have made their contribution to the development of a good theology of religion, and a little further off are the reflections of Douwe Klaas Wielenga JDzn (1905-1981) and Johannes Blauw (1912-2007).Their contribution to the development of a Reformed theology of religions, which I prefer to call theology of religion, is considerable and should not be underestimated as they have given thought to what the core of the Christian faith is in relation to the other religions. What they have not succeeded in doing is to develop a system or model by which to sort out or classify religion, religions and Christian faith and to assess them according to reliable criteria. ${ }^{1}$

It will be no surprise if I suggest that the greatest thinker in the field of theologia religionum is Hendrik Kraemer (1988-1965). It is tragic that this great authority on religion and religions at the end of his life was ignored and forgotten in the international forum of churches and missionary societies. In general after the General Meeting of the World Council of Churches in New Delhi in 1961 'traditional' missionary work was replaced by dialogue. Now certainly not all forms of dialogue are inappropriate as a method in mission. Since the sixties of the last century dialogue has been used for discussions between religions on an equal footing and with acknowledged equivalence. As such the preaching of the good news was progressively dispensed with. And yet the introduction of dialogue as a method of mission cannot exclusively be blamed for the rapid disappearance of the 'old' form of mission from the agenda of the 'mainstream' churches of the western world. Religious relativism, dramatically taking everything around itself in its grasp, has slain its ten thousands and is continuing its destruction of the motivation for mission. Later in the eighties of last century pluralism was given an almost general position in the mainstream of churches, as a result of which every form of preaching of the good news has become superfluous and inappropriate and all world religions were considered to be principally equal. All religions lead, after all, to the same goal, or all are directed to the same God or divine being. These are still the

1 J. H. Bavinck, An Introduction to the Science of Missions, trans. H. Freeman David (Philadelphia: The Presbyterian and Reformed Publishing Company, 1960); Paul J. Visser, Heart for the Gospel, Heart for the World, The Life and Thought of a Reformed Pioneer Missiologist Johan Herman Bavinck (1895-1964) (Eugene: Wipf and Stock Publishers, 2003), 257,279; C. J. Haak, Gereformeerde Missiologie \& Oecumenica: Beknopt Overzicht Aan Het Begin van de 21e Eeuw A.D (Zwolle: De Verre Naasten, 2005), 70. 
smallest heresies of religious theological thinking which we call pluralism. In the circles of the conservative, or more accurately the orthodox churches the decline of mission is regarded with melancholy, but the way of thinking which the theology of religions has to offer has in my opinion never properly got off the ground in the protestant churches belonging to the Reformed tradition.

That I value the adjective Reformed for the term theology of religion is not only because I prefer to take up a distinctive and clear position in the extremely pluriform world of the theology of religions. In a world which is characterized by religious pluralism the theories about the distinctive forms of religion and religiosity are necessarily many coloured and many sided. ${ }^{2}$ This theoretical diversity of classification models naturally has a relationship with religious disparity. The emergence of divisions and denominations within the Christian church also has an effect on clear distinction of differences between these groups and also on the categorisation of Christian belief, the religions and spiritual movements. As an example we can take the consultation of the department Faith and Order of the WCC and the National Council of Churches in the USA, Theological Resources for Responses to Religious Pluralism, held in the autumn of 1994 in Newark, New Jersey. During this meeting an internal discussion began about the interpretation by distinctive Christian denominations of the English term 'religious pluralism'. ${ }^{3}$ What became clear was how the various Christian traditions regarded the question of religious plurality. It emerged that religious diversity can quite clearly be seen and assessed from the broad spectrum of denominations within the Christian traditions. From for example the Spanish-American Pentecostal perspective, from the Reformed tradition, Mennonite theology, Methodist theology, Orthodox theological reflection, from Lutheran and Wesleyan traditions, etc. All these perspectives show that starting from a particular Christian tradition it is possible to map out religious diversity from one consistent vision or well-described confession, by making the criteria clear and subsequently to order and evaluate this pluriform religious reality.

It is necessary to verify and evaluate this multicoloured theology of religion thinking. Indeed this must take place from the general scientific criteria such as consistency, systematics comparison of methods and defensible conventions, etc. There must be clarity in respect of the prejudices and the internal religious values and norms. Another question is how far you can use a reformed theology of religion, starting from your own reformed tradition, to judge another system of thinking within the Christian spectrum. The one system of assessing religion and religions can never be better or higher than any other, but the starting points do make a difference. Criticism of a reformed system of assessment ought to be 'criticism from heaven', otherwise it is pointless. In the case of a theoretical system designed to assess religion and religions in theory the Biblical starting points must be beyond reproach. These are the a priori which are justifiable in

${ }^{2}$ Exclusivism is a characteristic in all religions and religious movements. In the criteria for classification which is generally employed nowadays exclusivism is not always listed. This is because the criteria which are applied for classifying religions are not necessarily borrowed from one's own religion or the internal religious values.

3 See S. Mark Heim, ed., Grounds for Understanding: Ecumenical Resources for Responses to Religious Pluralism (Grand Rapids: Eerdmans, 1995). 
choices of faith and which are to a limited extent capable of being localized cognitively. I cannot enter here into all epistemological questions, but I shall presently try to answer the question of what the Biblical criteria are on the basis of which religious awareness, religion and religions can be compared and classified. The nature, origins and breadth of religious knowledge is decided by religion and religions themselves. For the Christian religion this is on the one hand the limitation which is given together with the revelation and on the other by the limits that there are in the auxiliary sciences of the theology of religion.

That I choose for a contemporary theology of religion stems from my wish to develop a synchronic theology of religion model. The rear view mirror of diachronic review will be little used. That which is valuable in the historical developments of theology of religion will be included, but I shall not sketch a historical overview. The importance of the contemporary situation lies first and foremost in the possibilities and challenges in the post modern religious reality to have a theology of religion model that is defensible, workable and acceptable in the religious disparity of trends, directions and opinions in these days.

When under the inspiring guidance of my promoter I commenced research into the theology of religion thinking of Gustav Warneck, Hendrik Kraemer and Lesslie Newbigin I began to want to use their thinking to develop my own reformed theology of religion system. As my research progressed I had to let go of that ideal in order to limit myself to describing and comparing the theology of religion thinking of these men. I see this article as a first opportunity to sketch out a few lines for a reformed theology of religion model. It is an assignment and a straightforward challenge.

\section{B. Models and Possibilities}

In order that meaningful contact can take place between those confessing the reformed faith and representatives of today's religious movements or with the followers of the well known world religions it is vitally important that reformed Christians should have a clear concept of what religion is and what religions are. One the one hand they need to be clear about Biblical principles and on the other they must have an objective knowledge of the religions and religious movements and be able to debate the contents of them. For the first of these it is necessary to have a model or system of thinking which is fully based on the Biblical principles and which is generally applicable.

For the latter it is necessary that the data about the comparative religious sciences, the religious phenomenology and the philosophy of religion (which is known in the Anglo/Saxon world as the theory of religion) should be adequately and correctly applied in reformed theology of religion thinking. It is rather obvious that in reformed missiology the results of these scientific disciplines have not been optimally applied, while they are extremely important for gaining a responsible and broad knowledge of the phenomenon religion and various religions.

At the moment I feel that it is too much to say that comparative religious sciences, religious phenomenology and the philosophy of religion are mere neutral scientific disciplines, which must not be hindered by reformed 
assumptions. These three disciplines are least of all free from value judgements, although many claim that they are concerned with neutral, scientifically developed, objective knowledge of religion and religions. At this stage I content myself with sketching a theology of religion model which I to a significant extent develop from the thinking of Kraemer and Newbigin and which can and must be regarded as Biblical.

\section{Models in Theology of Religion-Exclusivism, Inclusivism, and Pluralism}

The actual meeting of representatives of whatever religions cannot take place without agreements, rules, and consideration of values and assumptions. On the plane of religious encounters there must be agreed rules, otherwise accidents occur. Scientific research among the comparative religious sciences can draw together a significant amount of trustworthy information about religions. If no value judgement can or may be attached to the data we do not get any further in the actual meeting of religion. The point is whether and how we can apply internal religious value systems without letting an honest meeting strand in a one-sided exchange of one's own egocentric religious standpoint. On the other hand the real danger exists of a pluralist standpoint that so consistently pushes through religious relativism so that the question of truth can only be answered individually. It is then a misconception that an agenda-less or presumption-less meeting can ever lead to a healthy result which promotes mutual respect. No-one wants war between the followers of religious societies and denominations. Furthermore it has been well demonstrated that the purposes of a religion ('religious ends') are not necessarily prescriptive for or convergent with the aims of religious concourse or theological discourse. A consistent relativist standpoint in religions or the practice of religion is never tenable. That is also the weak point in pluralism as the intellectual answer to religious disparity. Because of their immense religious disparity religions cannot be brought under one heading (e.g. the view of John Hicks that all religions are theocentric). Because there are so many different forms of religion they can hardly be compared with one another, even though they seem to show similarities on several points. Pluralism as a theology of religions position is the most confusing standpoint imaginable, because it does disservice to multicoloured religious reality and leads to a relativism with which no-one is content. A peaceful religious society will never be achieved if we pretend that all religions are in principle the same, all ways lead to the same objective, or originate from one god, etc.

I regard it to be the task of theology of religion to develop a model that on the one hand does justice to the actual religious disparity and is on the other hand justifiable within reformed doctrine, or better still, in the framework of Biblical principles. Since the 1980's it has become $d u$ bon ton in theory of religion to categorize religious differences and similarities according to the classification model that Alan Race has developed: exclusivism, inclusivism, and pluralism. The principle reason that I have used this model in my thesis is because this model is not only practical, but is generally known and used everywhere. I would however warn readers not to attach exaggerated value to this model, because Rice's categorizing principle is no more than an exhibition 
hall which can be useful to arrange all sorts of religions in order to decide which has precedence, which claims precedence, what importance a particular religion has, what is thought to be important, etc. Certain criteria are employed in this model in order to categorize religions. In the theory of religions literature we very soon find that this model is not only used to categorize the many-sided world of religion, but also to express value judgements about religions and the practice of religion. You know or recognise it: does a religion claim exclusive validity or do people give inclusive or relative values to a religion or to their own religion? Is a particular religious element unique or universal? And what is worse: is a universal element preferably regarded as more creditworthy than a sectarian element? Is an exclusive religion immediately suspect because it is a socially or politically incorrect element? Is the salvation of a particular religion only available to its own small group or does it have a universal application. Exclusivists and inclusivists agree with each other in this matter: In both models it is assumed that Christ's death etc. constitute salvation and they both refute that others who are outside of Christ have access to this salvation. Pluralists deny that any particularist event can offer salvation to mankind. Their un-explicated assumption that religions must promote salvation and peace implies that there are many true religions.

A British expert in the field of the philosophy of religion, Peter Byrne, assumes a fiveway split; naturalism, confessionalism (further split into exclusivism and inclusivism), pluralism, relativism and varieties in neutralism. Confessionalism as a system for the interpretation and categorization of religion, he regards as a principle of categorization which is based on a particular confession. For instance an assumption in ethics, the scheme of salvation, the revelation of the doctrine of a particular religion. According to Byrne this sort of confessionalism leads necessarily to the exclusion of all other religions (exclusivism) or to the acceptance of them on the basis of accepting a relationship which is in accordance with one's own (inclusivism). ${ }^{4}$

The American theologian Schubert M. Ogden holds in principle a fourth way open in addition to the three 'ways' of Alan Race. ${ }^{5}$ If Christianity is true - which Ogden acknowledges - then it is at the same time correct that also all other religions can be true in the same meaning because and insofar as they express the same religious truth, even though they differentiate constituent elements. For him what is important in the question of 'true' or 'not true'('false') in religions is the way is which it is decided how to represent the 'divine' in these basic elements. Ogden assumes too easily that the notion 'salvation' or 'redemption' in the diverse religions is the same, but this is surely not the case in all religions. The salvation that is established by God in the Christ-story is unique. Salvation in, for example, Buddhism is quite different from this. We must seriously consider whether there are any unifying factors in aim to be found in these two religions. Seen from the point of view of Christianity true religions

\footnotetext{
4 Peter Byrne, Prolegomena to Religious Pluralism: Reference and Realism in Religion (Houndmills: MacMillan Press Ltd, 1995), 1-4.

5 Schubert M. Ogden, Is There Only One True Religion or Are There Many? (Dallas: Southern Methodist University Press, 1992), 102; Heim, Grounds for Understanding: Ecumenical Resources for Responses to Religious Pluralism, 224.
} 
represent the love of God, but the representations of this through and in other religions produce other traditions and elements. Ogden's example shows that Race's system can be used in different ways. But the advantage is that the terms and the criteria which are laid down are recognizable and the communication between the various theology of religion models is thereby increased. In how far Ogden's 'fourth way' is a variation on 'inclusivism' is difficult to establish, because Race's three ways are applied in countless ways and consist of many varieties.

Now pluralism is often contrasted with exclusivism. And that is a natural and remarkable contrast because they are quite unlike each other. One would expect that pluralism in Race's system would be contrasted with religious individualism or particularism, but from the moment that this model was granted general validity in the world of theology of religion, the availability of the way of salvation and the claim to the truth has been for exclusivism and inclusivism an important criterion for judgement. Within pluralism as a position in the theology of religion the claims to the truth are regarded as extremely important. In the last few years what has emerged is that the principle of usefulness has become a more important criterion. In this respect Paul F. Knitter and Wilfred Cantwell Smith think of the promotion of salvation and world peace, prosperity and practical justice through various religious systems. That huge and fundamental religious diversity exists is not seen to be a problem, as long as there is unity in objectives which are useful, such as the fight against evil, the promotion of peace, etc.

Over against Race's model, the American S. Mark Heim has developed a fairly new categorization principle for weighing and classifying religions. In his study The Depth of the Riches: a Trinitarian Theology of Religious Ends from 2001 he offers a classifying principle for religions based on the aims and/or seclusion of religions. ${ }^{6}$ For Christianity that is of course salvation as the eventual unity with God's fullness. Earlier, in his study Salvations: Truth and Difference in Religion he had strongly criticized the pluralistic hypotheses of John Hick, Wilfred Cantwell Smith and Paul Knitter. ${ }^{7}$ According to Hick's pluralist hypothesis all religions are God-centred. However, the doctrine of God is just as little worked out in Hick's way of thinking. Cantwell Smith too developed a theological hypothesis that all religions and religiousness are capable of explanation and to classify according to a general characteristic of unity. This principle takes into account too insufficiently the theological considerations of disparity of the religions. Knitter's movement from theocentrism, via soteriocentrism to the highest objective of righteousness promoting religions can also according to Heim fail to provide an adequate criterion of judgement for religion. Pluralism as a system of thinking and judging religion, which supposes that all religions are concerned with the same, one central thought, for example that God, the Real, or the All-one is central to all religions, is according to Heim also untenable. It is not surprising that there is little interest among religious traditions to embrace the pluralist system of understanding oneself. The most significant point of Mark Heim is that he shows

${ }^{6}$ S. Mark Heim, The Depth of the Riches: A Trinitarian Theology of Religious Ends (Grand Rapids: Eerdmans, 2001).

${ }^{7}$ S. Mark Heim, Salvations: Truth and Difference in Religion (Mary Knoll: Orbis Books, 1995). 
in a convincing way that religions are phenomenologically plural, but then also so diverse that they are unable to be compared with each other. It is not possible to fit a religion or a religious theory onto all other religious principles. Heim has taken over from Nicolas Rescher the idea that pluralist religious theories must lead to accepting the exclusion of all others. ${ }^{8}$ The shortcoming of Mark Heim's Trinitarian theological thinking about religions is that he only takes one aspect and wants to indicate and classify all religions according to it.

Joseph Ratzinger, the pope Benedictus XVI, has also tried to position the attitude of Christianity towards the world religions. ${ }^{9}$ He does not escape the grip of the pluralist opinion of the majority, but neither can he free himself from the noose of his own ecclesiocentric assumption that the truth is decided by the tradition of the Roman- Catholic Church which has grown historically. Now Ratzinger shares with us the exclusivist standpoint that faith in Jesus Christ is the only saviour of the world, but he has criticism for the three positions of Race. This is because according to him a rash assumption of equality has been drawn of the problem of the religions as far as the question of salvation is concerned. And secondly there is insufficient differentiation of the religions as such. ${ }^{10}$ He illustrates this by posing the question: How does one know that the issue of salvation is bound up with all religions? Because Ratzinger does not make enough distinction between the data from the comparative religious sciences from the traditional religions and because his own ecclesiocentric criterion of judgement within traditional Christianity lies, he cannot do anything with Race's classification system. He would have been able to go so much further along the way of equating religious elements in the comparative religious sciences. If he had let go of his traditional churchcentred standpoint and had gone in search of an objective model and at the same time had sought for a criterion of judgement which lies outside the historical reality, his ideas would be more convincing.

With the help of Race's model there are many objective religious data which can be at least a help to answer the question whether and to what extent religious phenomena are comparable. In the various models which have been developed from Race's system we encounter, among others, the following subjects in the description and classification of historical religious phenomena, whereby all elements can be distributed on a scale from little or nothing to complete or absolute. The elements can also be further defined in terms of the specific nature of the religion. The definitive elements are:

1. 'The truth' is exclusive or plural (or individual)

2. Universality of salvation versus particularity

3. The absoluteness of the religion and the uniqueness of the way of salvation

4. Relativity and finality in the religion

5. Continuity and discontinuity between religions

8 Ibid., 141; Nicholas Rescher, The Strife of Systems: An Essay on the Grounds and Implications of Philosophical Diversity (Pittsburgh: University of Pittsburgh Press, 1985).

${ }_{9}$ Joseph Ratzinger, Faith, Truth and Tolerance: Christianity and the World Religions (Tielt: Lanoo, 2005).

10 Ibid., 41-42. 
TOWARDS A BIBLICAL THEOLOGY OF RELIGION ... (Dirk Griffioen)

6. Continuity and discontinuity (the relation) between 'above' and 'below' in religions

7. What is the being of the 'higher', the al-one, the 'numinous', the real, the ultimate reality, etc. In relation to mankind

8. The individual versus the collective in religion

9. Has religion come about by 'revelation' or is it 'from below'?

10. Historicity versus timelessness

11. The end of the religion -nature and position of the hereafter, or here and now.

In line with Calvin and Karl Barth an increasingly careful distinction has been made by Kraemer and Newbigin between the revelation by God as the beginning or core of the religion and the religion as the historical, human phenomenon, which is the human response (answer) to the revelation.

That a position which someone has taken up or has been given sometimes seems to be contradictory or inconsistent will not surprise us. Lesslie Newbigin described his own position in Race's model with subtle distinctions as follows:

"The position which I have outlined is exclusivist in the sense that it affirms the unique truth of the revelation in Jesus Christ, but it is not exclusivist in the sense of denying the possibility of the salvation of the nonChristian. It is inclusivist in the sense that it refuses to limit the saving grace of God to the members of the Christian Church, but it rejects the inclusivism which regards the non-Christian religions as vehicles of salvation. It is pluralist in the sense of acknowledging the gracious word of God in the lives of all human beings, but it rejects a pluralism which denies the uniqueness and decisiveness of what God had done in Jesus Christ."11

Before I go further into the relationship between revelation and (historical) religion in $\S 6$, I would first like in $\S 5$ to clarify the distinction between religiosity and religions.

\section{Religiocity and Religions}

It is important that we first make clear what the difference is between religiosity and religions. Not only does one come up against all kinds of things in the world of the spiritual, but the terminology is exceptionally confusing. The terms with which religion, religious feeling and religiosity are indicated are in principle just as varied as religious diversity. Of course scientists attempt to create order in all this. A corollary to this is whether and to what extent there is truth in all this religious diversity. Gordon D. Kaufman suggests that claims to have the truth are always made by individual, finite human beings who are to be judged by their incorrigibility and absoluteness. ${ }^{12}$ This means that the pluralistic concept can help all forms of dominance and exclusion needs to be considered and judged only in a truly democratic reaction.

So Kaufman also feels that the truth of religious system scan only be established in a democratic way. His position implies that religiosity and

11 Lesslie Newbigin, The Gospel in a Pluralist Society (Grand Rapids: Eerdmans, 1989), 182-83.

12 Gordon D. Kaufman, God, Mystery, Diversity: Christian Theology in a Pluralistic World (Minneapolis: Fortress Press, 1996), 187. 
religions are human and earthbound matters, a phenomenon from 'below' because the 'higher' is mysterious and not verifiable. ${ }^{13}$ In picture 1 religion is described as a phenomenon in which 'from below' something is said about 'above', the 'Ultimate Reality' or the 'Real' or God. There is no 'influence' from 'above' towards mankind. All religions are ways of picturing the world 'above'. The opinion exists that the phenomenon of divine revelation is recognized as such, but then as a product of Man's intelligence.

But what is 'religious experience' then? Since Rudolph Otto it is almost universally accepted that we must look at what is 'completely different'. He suggests that consciousness of a mysterium tremendum et fascinans must be understood as a response to the transcendent, the 'numinous'. William James describes religious feelings as principally mystical experiences.

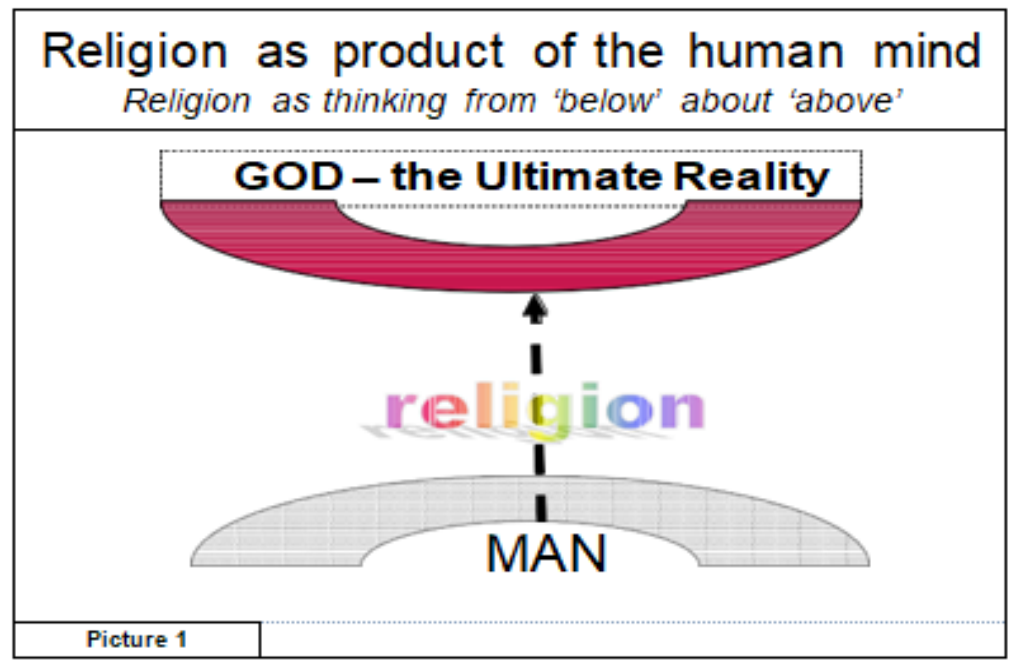

He names four characteristics of mystical experience: ineffability (inexpressibility, the experience cannot adequately be expressed in words), noetic quality (insight into deeper truth), transiency (the mystical experiences are of a temporary nature) en passivity (when the mystical experience begins, one becomes passive, because one is overwhelmed by a higher power). Of course this characterisation of mystical experience and experience of the 'numinous' makes us think of what J.H. Bavinck has written about religious awareness. Bavinck distinguishes five elements in this religious experience:

1. The experience of totality - the intimate unification with a greater whole, with all beings, in cohesion with the All-being life, in the light of the eternal being, etc.

2. The consciousness of norm - the Assurance that human behaviour is judged by something or someone, a moral norm, life and the World is an ordered World, a passageway in nature, a way.

3. Involvement with a Higher Power - a clear relationship or a vague bond with a higher power, a personal god, a Lord, a crowd of spirits or gods, an Upper Being, a deus otiosus, or an impersonal power which resides in

13 Gordon D. Kaufman, In Face of Mystery: A Constructive Theology (Cambridge: Harvard University Press, 1993), 301. God as the 'concept of an Ultimate Point of Reference' that must be constructed. 
the world. This authority has established a world order in which Man is subject in a living, inimical or in a broken relationship

4. The need for salvation- there is a longing for salvation from something, from imprisonment or slavery, from disasters or disease. It is usually a response to the declaration of the existence of evil. Often in connection with the belief that salvation is possible. Certain people or natural phenomena can offer this salvation.

5. (Inner) guidance for life - there is a strong connection between what happens around and above a person and his lot in life, which strengthens in him the consciousness of the relationship between action and fate. Human existence is interwoven in elements of earthly events. Sometimes this is called fate, sometimes one's lot which is determined by something or someone, which is not blind, no irrational chance, but which is regarded as being reasonable and just.

Bavinck emphasizes that the content of religious awareness is completely irradiated from the moment that one engages with a higher power. That consciousness is consistently given as the characteristic of religion. But this religious experience in which a person knows himself to be placed face to face with a 'secret Partner', together with the Other One who keeps himself hidden, comes under the heading of: answer. The response and processing by the person to the higher, or what he feels to be 'face to face' with him. Following on from his Tambaram book, The Christian Message in a non-Christian World, Kraemer repeated in his second great study Religion and the Christian Faith ${ }^{14}$ that Christians have access to God's revelation in Jesus Christ by means of the Bible, which he calls 'the record of the peculiar mode of God's self-disclosing activity'. Kraemer can go along with the anthropological pronouncement that it can be said of the 'human religious awareness' that it is: 'related to God - separated from Him; sought by God ... and haunted by Him - rebelling against Him and yet groping towards Him' Kraemer explains that it is as a result of the fall that man finds himself in this inevitable dialectic situation. By means of this rather dialectically characterized definition of religious awareness Kraemer states what is essential for religion and religions: the (religious) person stands under the judgement of God and is at the same time the subject of God's forgiveness. ${ }^{15}$

The well known writer Karen Armstrong analyses in her bestseller $A$ History of God the history of the concept of God. There she assumes that in the question of our consciousness of God it is to an important extent not a matter of whether and how God came down from on high, but rather that the religious (God) is a product of human creative imagination. Her 'history of God' is therefore not a description of the inexpressible reality of God, but a historical account of the way in which people throughout history have viewed Him. ${ }^{16}$ The question whether God is 'transcendent" or 'above' in respect of the 'below'

\footnotetext{
14 Translated in Dutch: H. Kraemer, Godsdienst, Godsdiensten En Het Christelijk Geloof (Nijkerk: Callenbach, 1958).

15 H. Kraemer, Religion and the Christian Faith (London: Lutterworth Press, 1956), 247, 251; Kraemer, Godsdienst, Godsdiensten En Het Christelijk Geloof, 958, 207, 210.

16 Karen Armstrong, A History of God, Four Thousand Years of Judaism, Christianity and Islam (New York: Ballantine Books, 1995), 12.
} 
existence of mankind is found to be totally irrelevant to Armstrong. Religious awareness is the human interpretation of an experience. To what extent this mystical or religious experience is caused by something or someone outside Man is not important. It is simply the human response, however mysterious. The religions of humankind, according to Bavinck, may differ in many ways, but they exhibit in some significant points of similarity. Religions are oriented to a few established points, namely the five cores, around which new structures can constantly grow and develop. ${ }^{17}$

Bavinck has correctly observed that we can only begin to understand from the point of view of God's wisdom what this 'religious awareness is, where it comes from and where it ends. ${ }^{18}$ In saying this he means that the Word of God is the only authority which can judge religious awareness and can assess what the value of it is, and what not. Whether it concerns real knowledge of God or not. In prominent dogmatics it is a disputed point whether and to what extent this religious awareness (or general religiosity - also known as the minimal religiosity of the majority ${ }^{19}$ ) is traceable to general revelation, or whether it is a phenomenon which belongs to being human, or whether it is the remnants of pre-Abrahamic revelation. ${ }^{20}$ Joahnnes Blauw in his article Rijmloos assumes a large measure of discontinuity between the religious answers and divine revelation. ${ }^{21}$ However he wants to get away from the simple difference between revelation as an objective fact of religious knowledge, and the subjective processing of it in the various forms of human religiosity. There is a relationship and discontinuity or antithesis. There are according to Blauw two values in religion, the divine and the human. With this, two things become clear, Namely that religion and religions are not simply human matters, but that there is also a question of some divine influence or activity in man or through man. Blauw does not go any further in his fundamental article into what precisely the divine element is or can be in religion or religions. As already noted, Karl Barth, following Calvin's example, makes a fundamental step forward in his distinction between revelation and religion as a historical phenomenon. Religion ist Unglaube, he suggested, religion is unbelief. And in doing so he puts all religion and religiosity under the criterion of divine revelation. Kraemer followed him in this. Also Newbigin assumes this as a starting point for his theology of religion. The latter has explicitly concentrated intensively on the question how God's revelation is or can be manifested in those who are followers of other religions than Christianity.

So we may conclude that it seems to be crucial from many standpoints how

17 J. H. Bavinck, Religieus Besef En Christelijk Geloof (Kampen: Kok, 1989), 188.

18 Ibid., 110.

19 A. F. Droogers, "'De Minimale Religiosity van de Meerderheid', [The Minimal Religiosity of the Majority]," in D. C. Mulder: Religies in Nieuw Perspectief,[Religions from a New Perspective] Offered to D. C. Mulder (Kampen: Kok, 1985), 88.

20 The idea that 'natural knowledge of God' is a God-given possibility is developed by, among others, J. Blauw, Goden En Mensen: Plaats En Betekenis van de Heidenen in de Heilige Schrift (Groningen: Niemeijer, 1950). He proposes that the existence of the non-christian religions 'heathendom' can be explained from the pre-Abrahamic revelation, which is reported in Genesis 1-11.

${ }^{21} \mathrm{~J}$. Blauw, "Rijmloos, Overwegingen Bij Het Thema: Evangelie En Religies," in Christusprediking in de Wereld (Kampen: Kok, 1965), 111-132. Studies in the field of missiology, dedicated to the memory of Prof. Dr. J. H. Bavinck 
one views religion and therefore religions: if one regards religion as a hundred percent human in origin. If religion is nothing more than human thinking or feeling about 'the higher' then the divine factor is no longer of importance in a particular religion. If the divine, the deity, 'the Real', 'the All' is seen to be the decisive element in religion, then the question cannot be avoided what the value of that constituent must be in that specific religion. In the final analysis it would seem that the question of revelation is decisive as a religious factor.

\section{E. Revelation and Religion}

The basic proposition that God has spoken in the Bible is enough in the daily life of a Christian to show what he bases his criterion on for the truth. If we hold the Bible as a book of the revelation against the light of scripture itself, then we can explain more clearly that God has spoken to the prophets and apostles, who subsequently have written His word down. That is what we call the revelation. This revelation is laid down in the Scriptures, which we call the Word of God.

In the 1ST paragraph of the Barmen Declaration of 1934 an important element is referred to while referring to John 14:6 and 10:9, which underlines the primacy of the Word of God:

Jesus Christ as he is attested to us in the words of Holy Scripture is the one Word of God whom we have to hear and whom in life and death we have to trust and obey. We reject the false doctrine that the church could and should recognize as a source of its proclamation, beyond and besides this one Word of God, yet other events, powers , historic figures and truths as God's revelation.

This establishes the continuity between God's revelation in Jesus Christ and the absolute importance of the Word of God, although the relationship between revelation and the Word of God is not explained further. According to Kraemer divine revelation is in any event essential for the formation of religion. Religion is the human response to God's revelation. Picture 2 illustrates the possibility of variation in human responses to God's revelation. Religion as a historical phenomenon can be a 'pure' response, completely in agreement with God's revelation, but can also deviate from it. In practice it is extremely difficult in Christianity as a human and historical phenomenon to distinguish what the divine revelatory elements are and what the human factors in the religion. In Newbigin we find a particular application of the Missio Dei concept.

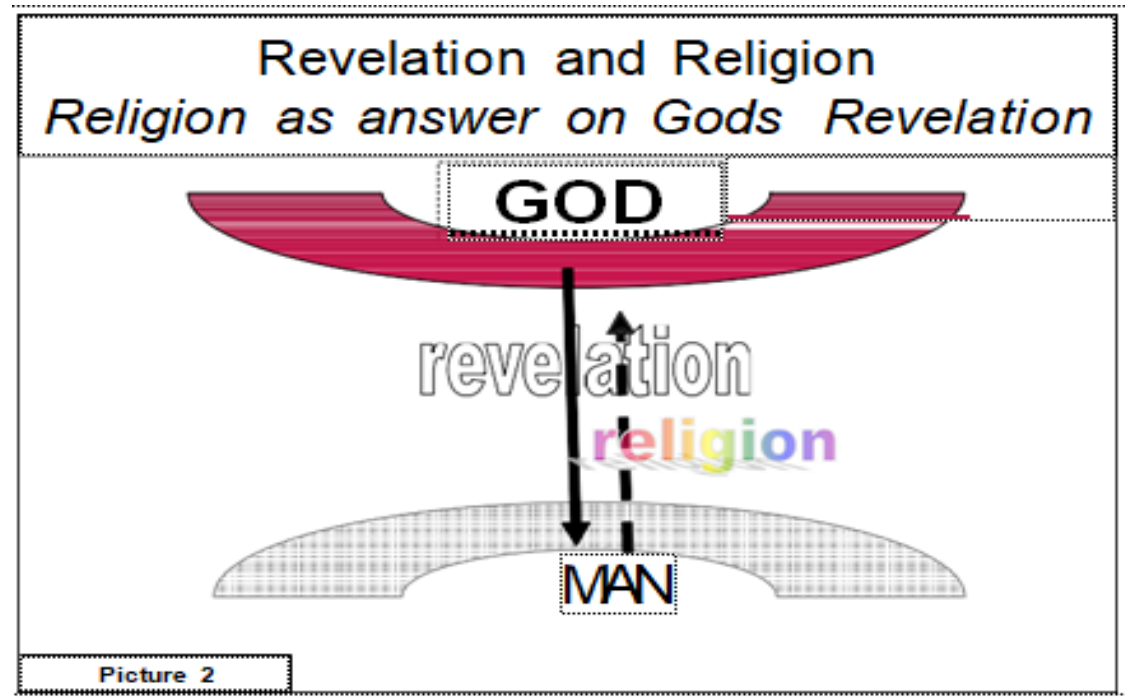


Human knowledge of God is only and exclusively obtainable because God has revealed himself to man. The religion of the triune God begins with 'God's mission'. The human history of serving God is therefore a response to and a processing of the Missio Dei. All mission of the Christian religion begins there. ${ }^{22}$ The question whether God's revelation has only and exclusively come to those to whom he has revealed himself, and through their witness in the Scriptures has come down to us, or also in other ways, is a question which Kraemer and Newbigin in any case have further contem- plateed in regard to the question whether and to what extent God's revelation occurs in other (historical) religions. Kraemer has pointed out that revelation is a Universal concept. What God reveals of himself is in the strict sense inaccessible for man and remains so. What God in his sovereign way reveals becomes recognizable by man. God, as giver of the knowledge of himself, has the supreme authority over the revelation. ${ }^{23}$ Faith in God is the effect of the revelation, which comes to man as a trustworthy witness. Christianity as a total religious system' is to be sure a historical phenomenon, radically different from the non-christian religions. Therefore Christianity, because of the constituent divine revelation on which it is based, also stands in an antithetical relationship to the other religions. The similarities in form and elements between Christianity and non-christian religions can be evident and superficial but never fundamental. The constituent divine revelation which is essential for Christianity is unique and as such not comparable.

That the religious outward signs of the diverse religions and movements can be compared with each other will not surprise anybody. Whether the apparently comparable outward signs also concern the same intentions or objectives is difficult to verify. In consideration of Kraemer's descriptions and assessments of religion and religions it must be noted that he set himself the strict demand to be extremely careful and scientifically responsible in his work in gathering, categorizing and judging the data. Richard J. Plantinga has pointed out that Kraemer by adopting his fairly restricted and in any event simplified concept of triunity, which seems to have been swallowed up by his christocentrism as well as by his hesitant concept of revelation, has limited himself in indicating the non- christian religions and the outward signs of the other religions. And yet his work in describing and assessing the other religions is acknowledged by friend and foe alike. The existence of divine revelation outside of Christ in other religions he has admitted because Kraemer with Calvin, Brunner and others recognize the pronouncement of Paul that there is something in man which in the end is rooted in God (theos) and cries out for the Word (logos)' as Plantinga says in comparison with the Japanese Masatoshi Doi. For if there is something of the divine which shines through the religions of the world, then according to Doi there must be revelation present in the non-

22 Frank Petter, Profanum et Promissio, Het Begrip Wereld in de Missionaire Ecclesiologie van Hans Hoekendijk, Hans Jochem Margull En Ernst Lange (Zoetermeer: Boekencentrum, 2002), 57.

23 Hendrik Kraemer, The Christian Message in a Non-Christian World (London, 1938), 69; D. Griffioen, Christelijke Zending En Wereldgodsdiensten: De Godsdiensttheologie van Gustav Warneck, Hendrik Kraemer En J. E. Lesslie Newbigin in Context (Zoetermeer: Boekencentrum, 2007), 203. 
christian religions. ${ }^{24}$

Newbigin liked to speak about the 'validity and finality of the revelation'. By this he meant that revelation in addition to normative values has also affected the culture in which the churches as keepers of the revelation grew up and developed. That the possibility exists that revelation is present in other religions, Newbigin has not accepted in so many words, because he did not regard himself as being capable of making any pronouncement on that score. He did however notice in the religiosity and the lifestyle of many followers of nonchristian religions the effects of the work of the Holy Spirit. He felt that this could only be explained as the working of God's Spirit in people. And Newbigin had learned from Kraemer not to despise the noble elements in the other religions. ${ }^{25}$ He maintained with Kraemer that such positive matters are not traceable to revelation, but to God's different ways of working in people. ${ }^{26}$

The question for Newbigin is: is there an original self revelation of God in the non-christian religious experience? Like A.G. Hogg he states that this to a certain extent is so. Hogg distinguishes between the content (consistence) and the happening (occurrence) of the divine revelation. According to him in all religions there is something of the content of revelation, because this is written in Scripture and is taken over into tradition. He considers this to be proven by the fact that it has been possible over twenty centuries to translate the Word of God into the language of another culture and to adequately communicate the message of God in Christ. Hogg claims that in the communicating of Christian faith use has gratefully been made of the content of non-christian religious concepts and terms which are used in all languages. Newbigin quite rightly notes that the possibility to understand something of God's revelation. Brunner calls this the Offenbarungsfähigkeit, because man should be approachable and responsible to Gods revelation. This doesn't mean that there is actually something in the other religions of God's self revelation. The process of appropriation of the content of the Biblical revelation can only happen after the Spirit has brought about a change in (the religious feelings of) the people, in the sense that they must be prepared by the Spirit and made receptive to translate into their religious life this revealed knowledge of God by means of getting to know the Word. ${ }^{27}$ This I regard as one of the cruxes of reformed theology of religion. There remain the questions whether man (naturally) is receptive for revelation and then whether God's revelation is present in other religions.

An ultimate test for an open approach to the question whether and to what extent there can be divine revelation in the other religions occurs for instance in meeting with Muslims. After all the followers of the prophet Mohammed believe that they have received in the Koran the ultimate revelation of Allah (God) to the prophet. To judge this from the human point of view this claim to revelation is neither verifiable nor deniable. In fact if we consider the revelation of God in

${ }^{24}$ Richard J. Plantinga, "Missionary Thinking about Religious Plurality at Tambaram 1938: Hendrik Kraemer and His Critics," in The Changing Face of Christianity: Africa, the West and the World, Oxford, ed. Lamin Sanneh and Joel A. Carpenter (New York: Oxford University Press, 2005), 149-190.

${ }^{25}$ Lesslie Newbigin, The Finality of Christ (London: SCM Press, 1969), 25-26.

26 Ibid., 35.

27 Ibid., 36-38; Alister McGrath, The Open Secret: A New Vision for Natural Theology (Malden: Blackwell, 2009), 158-64. 
Jesus Christ we see that this claim can really be verified. Thus for Muslims the revelation of God to the prophet is truth, whilst the Biblical revelation is regarded quite differently. From a Bible-based theological point of view the revelation of Allah to the prophet can only be accepted as truth if the revelation is consistent with Scriptural revelation. From the point of view of religious phenomenology there exist only the differences and consistencies between the Bible and the Koran. Seen from the standpoint of the Biblical revelation the Koran is a pseudo-revelation. Viewing their claim from the Gospel, the message of the Koran is another gospel. It is not superfluous to say that in practical meetings with Muslims it is very difficult to make this point clear. Although this characterisation may be made on grounds of the divine revelation and although it is based on the actual differences in these two sorts of revelation, this conclusion is often not judged respectfully. In a strict sense the Christian claim to truth which is based on revelation is exclusive and by definition the other religion(s) are therefore precluded. This claim is too easily judged to be arrogant and judgemental. The revelation of God is according to the Christian faith unique and exclusive and therefore not to be compared with other claims of revelation. In exactly the same way for the Muslims the claim to exclusivism is unique and final as a result of the revelation to Mohammed. What is different from Christianity is that Islam maintains her exclusive claims to the historic and cultural outward signs. The claim to truth in both these religions as historical facts cannot be decided on theological bases, because the question of truth is finally decided by the religious criteria and presuppositions.

For Kraemer it is essential, if one is to be realistically Biblical, to accept as a fact that his concept of revelation - that God's revelation is in Christ, who is the way, the truth and the life - is the key to the so-called "offensive exclusivism regarding ultimate truth" of Christianity and that it needs to remain so because this is the core of the Biblical message. Christians therefore claim exclusivity not because they have got the truth, but because the truth (= Jesus Christ) has got them. ${ }^{28}$

This is the place to pause and consider the possibility of the presence in pure or corrupted form of God's revelation in other religions. Thinkers such as William E. Hocking ('world faith'), John Hicks (all religion is God-centred) and just about all pluralists assume that there is no religion without God or a revelation of God. Exclusivists and inclusivists do not deny the possibility of the presence of (elements of) the revelation of God in other religions; the question is what and where? J.H. Bavinck, Johannes Blauw and others accept the possibility of God's revelation of himself in religions, but hesitate to call it that, or to point it out specifically. It is generally accepted in the Reformed world, following Calvin's example, that the sensus divinitatis has more to do with the possibility of developing or producing a knowledge of God, than that a real knowledge of God might be present in (and part of) man. The concept of sensus divinitatis can only be understood against the background of Calvin's negative opinion of all human religiosity (man is a manufacturer of idols) and Barth's 'Religion ist Unglaube'. Here we find ourselves in the realm of elencticism.

${ }^{28}$ Kraemer, Religion and the Christian Faith, 373. 


\section{F. Historical Religion(s) and Christianity}

Much could be said about the gaps in Kraemer's and Newbigin's theories but not that they give undue value or absolute weight to Christianity as a historical phenomenon. The claim of the finality of Christianity, which is deplored by many because it could lead to the exclusiveness of Christianity, is based on the absoluteness of the revelation, not on Christianity as a historical phenomenon. Newbigin never regarded Christianity as unique, but he did regard the finality of God's revelation (in Christ) as that. That exclusivity is embodied in the unique character of the revelation which has formed Christianity and still gives form to it and develops it in a changing world. It is not contained within the Christianity which was historically developed.

After the discussion at the International Missionary Conference in Tambaram in 1938, Kraemer admitted that a certain measure of continuity has to exist between the 'naturalist religions of human self-realisation and the religion which is a response to God's revelation. ${ }^{29}$ As far as I have been able to ascertain Kraemer never made a substantiated attempt to demonstrate what the actual continuity is between Christianity and the other religions. Newbigin however has helped us a little further by indicating how the working of God's Spirit in the lives of the followers of non-Christian religions can be seen. And also in the possibility that man can understand and process the evidence of God's revelation there is the proof that he is made 'receptive' by God to be able to believe. Kraemer recognizes the fact that the processed revelation has in the course of the centuries become normative for the faith and life of the Christian. The historically formed Christianity was the norm upon which the other religions and the lives of their followers were judged. It was always clear in the Christian church that religion and religions must be judged as to their truth or falsehood on the basis of divine revelation, the Word of God. Kraemer, following particularly Karl Barth's example, also subjected Christianity as a historical phenomenon, as a 'religion', to the criticism of the revelation. In doing so it was precluded that Christianity should be regarded as better or higher than any other religion, because the revelation of God (in Christ) is the ultimate criterion against which all religion and each religion including Christianity must be judged. For Newbigin this line of thought runs from Calvin, via Barth and Kraemer. For all these persons mission, with its ultimate call to faith and conversion remains pre-eminent, without there being any question of a feeling of superiority in Christianity or the Christian faith.

In the thinking of Roman Catholic leaders such as Ratzinger one can sense in all nuances that the historically determined traditions of the Catholic church tend towards absolutist values. It is correct that the ecclesiocentric standpoint in the literature is labelled exclusivist, for however one twists or turns, the proposition still remains of decisive character: 'outside the church there is no salvation'. In the case of all representatives of 'inclusivism' who had their origins in the $\mathrm{RC}$ church it is noticeable that they comment in great innocence on the presence of Knowledge of God and elements of God's revelation in other religions. That can be expressed in the opinion that in all religions the love of

${ }^{29}$ H. Kraemer, "Continuity or Discontinuity," in Tambaram Series Vol. 1. The Authority of the Faith (New York, 1939), 1-21. 
God is made known. ${ }^{30}$ Or as Ratzinger himself formerly suggested that the non-Christian religions contain 'preparatory' elements for Christianity. ${ }^{31}$ According to the declaration of Vatican II in respect of the attitude of the church towards the non-Christian religions Nostra Aetate. ${ }^{32}$ the other religions reflect a 'ray of the truth which illuminates all people'. ${ }^{33}$ In Ratzinger two concerns are intertwined. On the one hand he employs his exclusivist assumption that salvation is for the individual and is only attainable by faith in Christ, but on the other hand this statement is under pressure because he wants to leave room for the opinion that in the non-Christian religions there are traces present of the knowledge of God which contain elements of salvation. The real tension is seen when Ratzinger starts defending the age-old ecclesiocentric doctrine that the RC church is the guardian and keeper of the truth, because according to him the RC church possesses the true and pure representation of Jesus Christ on earth. Thus the church tradition attains the absolutist value and not divine revelation.

Quite recently Jan A.B. Jongeneel has taken the discussion about the relationship between historically formed Christianity and the importance of the revelation for the church and Christianity significantly further. Jongeneel positions himself in the long tradition which we have already noticed in the names of Calvin, Barth, Kraemer and Newbigin, who each with his own accents also took as their starting point the difference between religion, in the sense of historical religion, and God's revelation. Jongeneel in his most recent study describes the continuous interaction between Christianity and the nonChristian religions, philosophies and ideologies in world history. ${ }^{34}$ In this he turns his attention completely to the person and work of Jesus Christ. Throughout the centuries Christians and Christian communities have exercised influence on their environment and conversely they have also been changed by their own context. Jongeneel initially concerns himself with how the presence and the representation of Jesus Christ took place in the course of history. First he describes how the presence of Jesus Christ occurred in world history, the world religions and worldviews, subsequently how the representations of Jesus Christ in authentic and alas also in misrepresentations have taken place through his individual followers and the distinct Christian (and non- Christian) institutes.

Jongeneel's study shows quite clearly how the two most important elements in the theology of religion, the revelation of God in Jesus Christ and the historical, cultural and human factors have formed and changed Christianity in a

30 Thomas Ohm, Die Liebe Zu Gott in Den Nichtchristlichen Religionen (Freiburg, 1957).

31 Joseph Ratzinger, "Die Christliche Glaube Und Die Weltreligionen," in Gott in Welt, K. Rahner on His 60th Birthday, ed. J. B. Metz et al. (Freiburg: Wien, 1964), 287-305; Joseph Ratzinger, Truth and Tolerance: Christian Belief and World Religions, trans. Henry Taylor (San Fransisco: Ignatius Press, 2003), $18-44$.

${ }^{32}$ Nostra Aetate, Hilversum: Gooi En Sticht, 1966, 7.

33 Miikka Ruokanen, The Catholic Doctrine of Non-Christian Religions: According to the Second Vatican Council (Leiden: Brill, 1992); Josef Heislbetz, Theologische Gründe Der Nichtchristlichen Religionen, [Theological Grounds for Non-Christian Religions] (Basel: Wien, 1967).

34 Jan A. B. Jongeneel, Jesus Christ in World History: His Presence and Presentation in Cyclical and Linear Settings (Frankfurt: Peter Lang, 2009), 1-8. 
correlative process. Both factors are of course not the same, because the revelation is independent and sovereign, whilst the human factor is at least variable and certainly dependent on the revelation. All the time both factors are distinguishable in perceptible, historical Christianity, even though it often seems to be difficult in the concrete situation to indicate the distinction. What is clear is that Kraemer, following on from Calvin and Barth, has indicated the deepest possible element for the comparison and assessment of religion and religions: divine revelation.

\section{G. Uniqueness, Absoluteness, and Relativism}

Despite everything it seems to be difficult for Christians if they go outside their normal environment to safeguard their claim for the exclusivity of Christianity against any reproach of arrogance and self-satisfaction. It is not only as a result of the negative association that the terms uniqueness, finality and exclusiveness have received in our time that the suspicion of imperialism and fundamentalism is pronounced on Christianity. Many Christians themselves are infected by the relativism of the postmodern time which makes them allergic for absolutist claims and 'imperialist' thinking. It is important in the actual meeting with representatives of other religions and movements to make clear that the exclusivist and absolutist claims of Christianity have nothing to do with the historical institute of Christianity, but rather with the source and norm of Christianity, the revelation of God in the person of Jesus Christ. ${ }^{35}$ Of course each religion may have a fair chance to plead its case and there must be tolerance which guaranteed objectivity for all partners concerned in the discussion. In an honest religious dialogue, such as proposed by Lesslie Newbigin, the finality of God's revelation must be pre-eminent. ${ }^{36}$ The Christian's own religious convictions, according to Newbigin, are moulded by this approach to the Gospel.

The aspect of the uniqueness of a religion gives no reason to pronounce any suspicions about it, despite the derogatory reports from the camps of the pluralists. The pluralist position in the theology of religion appears to be getting the best results to do justice to the diversity and the individuality of all religion and religions. The value of comparison, testing and judging of each discrete religion cannot be given in pluralism or can only be indicated as inherent, since principally all religions are equally true and therefore everything in the religions must be relative. A Reformed theology of religion can at this point make a huge improvement by maintaining emphatically that the only criterion for judging the issue lies outside Christianity, namely revelation.

The attempt of Perry Schmidt-Leukel to indicate religious diversity theologically must end in disaster. After all, from a Biblical understanding, there is fundamental criticism for this relativist system. His suggestion for a 'polycentric pluralism' must also end up in an unworthy approach to and

35 Hendrik Kraemer, Waarom Nu Juist Het Christendom?[ Why Now Particularly Christianity?] (Nijkerk: Callenbach, 1960), 103.

${ }^{36}$ Lesslie Newbigin, "The Basis, Purpose and Manner of Inter-Faith Dialogue," in Scottish Journal of Theology, Vol. 30, 1967, 253-270. 
description of all religious phenomena and the other religions. ${ }^{37}$ Quite apart from his basic assumption about what religion is and what the function and significance is of religion or of each religion separately.

\section{CONCLUSION}

It is now time to attempt to draw up an outline for a theology of religion which justifiably can be called Biblical or Reformed. The following assumptions need to be borne in mind in designing this:

1. Religion is a universal human phenomenon, a creative fact and is a priori a relationship with God or 'the higher'.

2. Religion and religions, Christianity and non-Christian, are phenomena and/or institutes which are to be described, compared and judged.

3. The only criterion of judgement for religion is the revelation of God in Jesus Christ..

4. Religious pluralism is a creative fact which must be judged from the standpoint of God's revelation. 38

5. That all religions claim exclusiveness need not lead to religious relativism, nor to intolerance, denunciation, etc. Christianity is unique because its criterion for judgement comes from outside: divine revelation.

6. Religious awareness can be collective, whilst the postmodern religious feeling, is individually experienced, but has collective roots. Postmodern religious feeling can despite being principally unstructured and unconventional take on institutional form, but otherwise it allows universal claims to apply.

Taking the above assumptions into account, the following subjects come onto the agenda for the Reformed theology of religion:

1. In the relationship between God and man revelation is decisive: what is religion according to the revelation.

2. Religion as a response to God's (general, special or Christ's) revelation should be described and compared as a human phenomenon: what is the cultural, human factor and what is the divine element.

3. The face of the church and Christianity must be charted, what is permanent in form and content and what is changeable and can change.

4. The term revelation does not need to be given only a dogmatic and Biblical meaning, but should also be brought into rapport with the data and results of the sciences of religion and religious philosophy.

5. The conversation, the meeting and the dialogue with other religions should begin with a setting out of the criteria, the presuppositions and the objectives.

6. Postmodern religiosity is a form of religion which should be described

37 Perry Schmidt-Leukel, "Pluralism: How to Appreciate Religious Diversity Theologically," in Christian Approaches to Other Faiths, ed. Paul M. Hedges and Alan Race (London: SCM Press, 2008), 85110.

${ }^{38}$ Calling this universal creative fact an unbeliefs fact, would imply an elenctic judgement. In the strict sense religion as a relationship with God existed in the garden of Eden before the fall. Religion and religions have become since the fall plural phenomena, whereby all mankind literally went their own ways in their religious expressions and experiences. 
TOWARDS A BIBLICAL THEOLOGY OF RELIGION ... (Dirk Griffioen)

and approached from the standpoint of God's revelation.

\section{REFERENCES}

Aetate, Nostra. Hilversum: Gooi En Sticht, 1966.

Armstrong, Karen. A History of God, Four Thousand Years of Judaism, Christianity and Islam. New York: Ballantine Books, 1995.

Bavinck, J. H. An Introduction to the Science of Missions. Translated by H. Freeman David. Philadelphia: The Presbyterian and Reformed Publishing Company, 1960.

- - - Religieus Besef En Christelijk Geloof. Kampen: Kok, 1989.

Blauw, J. Goden En Mensen: Plaats En Betekenis van de Heidenen in de Heilige Schrift. Groningen: Niemeijer, 1950.

——_. "Rijmloos, Overwegingen Bij Het Thema: Evangelie En Religies." In Christusprediking in de Wereld. Kampen: Kok, 1965.

Byrne, Peter. Prolegomena to Religious Pluralism: Reference and Realism in Religion. Houndmills: MacMillan Press Ltd, 1995.

Droogers, A. F. “'De Minimale Religiosity van de Meerderheid', [The Minimal Religiosity of the Majority]." In D. C. Mulder: Religies in Nieuw Perspectief,[Religions from a New Perspective] Offered to D. C. Mulder. Kampen: Kok, 1985.

Griffioen, D. Christelijke Zending En Wereldgodsdiensten: De Godsdiensttheologie van Gustav Warneck, Hendrik Kraemer En J. E. Lesslie Newbigin in Context. Zoetermeer: Boekencentrum, 2007.

Haak, C. J. Gereformeerde Missiologie \& Oecumenica: Beknopt Overzicht Aan Het Begin van de 21e Eeuw A.D. Zwolle: De Verre Naasten, 2005.

Heim, S. Mark, ed. Grounds for Understanding: Ecumenical Resources for Responses to Religious Pluralism. Grand Rapids: Eerdmans, 1995.

- - Salvations: Truth and Difference in Religion. Mary Knoll: Orbis Books, 1995.

- - - The Depth of the Riches: A Trinitarian Theology of Religious Ends. Grand Rapids: Eerdmans, 2001.

Heislbetz, Josef. Theologische Gründe Der Nichtchristlichen Religionen, [Theological Grounds for Non-Christian Religions]. Basel: Wien, 1967.

Jongeneel, Jan A. B. Jesus Christ in World History: His Presence and Presentation in Cyclical and Linear Settings. Frankfurt: Peter Lang, 2009.

Kaufman, Gordon D. God, Mystery, Diversity: Christian Theology in a Pluralistic World. Minneapolis: Fortress Press, 1996.

- - - In Face of Mystery: A Constructive Theology. Cambridge: Harvard University Press, 1993.

Kraemer, H. "Continuity or Discontinuity." In Tambaram Series Vol. 1. The Authority of the Faith. New York, 1939.

-_- Godsdienst, Godsdiensten En Het Christelijk Geloof. Nijkerk: Callenbach, 1958.

- - - Religion and the Christian Faith. London: Lutterworth Press, 1956.

Kraemer, Hendrik. The Christian Message in a Non-Christian World. London, 1938.

-_- Waarom Nu Juist Het Christendom?[ Why Now Particularly Christianity?]. Nijkerk: Callenbach, 1960.

McGrath, Alister. The Open Secret: A New Vision for Natural Theology. Malden: Blackwell, 2009.

Newbigin, Lesslie. “The Basis, Purpose and Manner of Inter-Faith Dialogue.” In Scottish Journal of Theology, Vol. 30, 1967.

-_- The Finality of Christ. London: SCM Press, 1969.

-_- The Gospel in a Pluralist Society. Grand Rapids: Eerdmans, 1989.

Ogden, Schubert M. Is There Only One True Religion or Are There Many? Dallas: Southern Methodist University Press, 1992. 
Ohm, Thomas. Die Liebe Zu Gott in Den Nichtchristlichen Religionen. Freiburg, 1957.

Petter, Frank. Profanum et Promissio, Het Begrip Wereld in de Missionaire Ecclesiologie van Hans Hoekendijk, Hans Jochem Margull En Ernst Lange. Zoetermeer: Boekencentrum, 2002.

Plantinga, Richard J. "Missionary Thinking about Religious Plurality at Tambaram 1938: Hendrik Kraemer and His Critics." In The Changing Face of Christianity: Africa, the West and the World, Oxford, edited by Lamin Sanneh and Joel A. Carpenter. New York: Oxford University Press, 2005.

Ratzinger, Joseph. "Die Christliche Glaube Und Die Weltreligionen." In Gott in Welt, K. Rahner on His 60th Birthday, edited by J. B. Metz, W. Kern, A. Darlapp, and H. Vorgrimler. Freiburg: Wien, 1964.

-_- Faith, Truth and Tolerance: Christianity and the World Religions. Tielt: Lanoo, 2005.

- - - Truth and Tolerance: Christian Belief and World Religions. Translated by Henry Taylor. San Fransisco: Ignatius Press, 2003.

Rescher, Nicholas. The Strife of Systems: An Essay on the Grounds and Implications of Philosophical Diversity. Pittsburgh: University of Pittsburgh Press, 1985.

Ruokanen, Miikka. The Catholic Doctrine of Non-Christian Religions: According to the Second Vatican Council. Leiden: Brill, 1992.

Schmidt-Leukel, Perry. "Pluralism: How to Appreciate Religious Diversity Theologically." In Christian Approaches to Other Faiths, edited by Paul M. Hedges and Alan Race. London: SCM Press, 2008.

Visser, Paul J. Heart for the Gospel, Heart for the World, The Life and Thought of a Reformed Pioneer Missiologist Johan Herman Bavinck (1895-1964). Eugene: Wipf and Stock Publishers, 2003. 